ISSN : 2615-1995, E-ISSN : 2615-0654

J. Madani., Vol. 1, No. 2, September 2018 (383-396)

(C)2018 Lembaga Kajian Demokrasi MADANI

dan Pemberdayaan Masyarakat (LKD-PM)

\title{
PENGARUH BIAYA OPERASIONAL TERHADAP PROFITABILITAS (STUDI KASUS PADA PT GEMILANG ABADI)
}

\author{
Sutiman \\ Fakultas Ekonomi, Universitas Pamulang \\ soetiman2014@gmail.com
}

\begin{abstract}
Abstrak
Penelitian ini bertujuan untuk mengetahui pengaruh biaya operasional terhadap profitabilitas pada PT Gemilang Abadi. Metode penelitian yang digunakan metode deskriptif dengan pendekatan asosiatif dengan data laporan keuangan tahun 2013-2017. Hasil penelitian biaya operasional dalam 5 (lima) tahun jumlahnya berfluktuatif. Tahun 2010 biaya operasional sebesar Rp.8.548.784.553, tahun 2011 turun mengalami penurunan menjadi Rp.7.125.514.453, tahun 2012 mengalami kenaikan menjadi Rp.8.920.022.175, tahun 2013 turun menjadi Rp. 8.762.891.353 dan tahun 2014 mengalami kenaikan menjadi Rp.8.867.594.334. Profitabilitas presentasenya berfluktuatif. Tahun 2010 profitabilitas sebesar 8,51\%, tahun 2011 sebesar 7,12\%, tahun 2012 mengalami kenaikan menjadi 8,36\%, tahun 2013 menjadi 6,23\% dan tahun 2014 sebesar 8,01\%. Pengujian statistik diperoleh persamaan regresi $Y=2,573+0,001 x$ diartikan jika biaya operasional tidak dipertimbangkan atau $(X=0)$ maka profitabilitas adalah sebesar 0,001\%. Koefisien korelasi diperoleh 0,886 dan determinasi sebesar 0,785 atau 78,5\% sedangkan sisanya $21,5 \%$ dipengaruhi oleh faktor-faktor lain. Uji hipotesis diperoleh $t_{\text {hitung }}>t_{\text {tabel }}(3,313>3,182)$ dengan demikian hipotesis yang menyatakan terdapat pengaruh positif dan signifikan antara biaya operasional terhadap profitabilita dapat diterima.
\end{abstract}

Kata Kunci : Biaya Operasional dan Profitabilitas.

\section{PENDAHULUAN}

\section{Latar Belakang}

Di era globalisasi dunia, ada fenomena baru dunia usaha yaitu terjadinya pergeseran titik perhatian dari pemberdayaan keunggulan komparatif menjadi pemberdayaan keunggulan kompetitif guna memenangkan persaingan usaha. Persaingan yang semakin ketat mengharuskan perusahaan untuk mengambil tindakan yang tepat agar dapat tetap eksis sesuai dengan konsep going concern. Oleh karena itu, perusahaan harus melaksanakan berbagai kebijaksanaan untuk mencapai tujuan utamanya yaitu untuk memaksimalkan laba yang dicapai melalui peningkatan penjualan produk atau jasa perusahaan serta melakukan efisiensi biaya diberbagai pos anggaran.

Pada berbagai segmen pasar yang dengan tingkat persaingan yang kompetitif harus ditandai dengan peningkatan permintaan dan usaha internal untuk menghemat biaya dengan demikian usaha untuk tetap menjaga kelangsungan hidup dan berkembangnya perusahaan dapat dijalankan dengan baik, maka manajemen perusahaan dituntut untuk dapat melihat dan menerapkan kebijakan atas kemungkinan dilakukannya optimalisasi biaya.

Manajemen perusahaan harus mampu mengatur segala sesuatu yang dapat mempengaruhi seluruh proses dalam perusahaan. Jika hal tersebut dapat dilaksanakan, maka pencapaian tujuan perusahaan akan lebih mudah 
untuk dicapai. Perhitungan atas biaya-biaya yang timbul dengan tepat sangat berguna, sehingga perusahaan diharapkan dapat bersaing secara kompetitif dengan perusahaan competitor yang menghasilkan produk maupun jasa yang sejenis.

Laba atau profit merupakan salah satu faktor kesuksesan perusahaan yang dan salah satu tujuan pokok perusahaan, supaya perusahaan tetap bertahan hidup dan berkembang lebih lanjut untuk jangka panjang pendek dan jangka panjang(Nafarin, 2007). Dengan demikian suatu perusahaan tidak dapat bertahan dalam jangka panjang dan mencapai tujuan lain sebagaimana telah direncanakan apabila perusahaan tersebut tidak mampu meningkatkan pendapatannya.

Pentingnya laporan keuangan sebagai informasi dalam menilai kinerja perusahaan merupakan syarat bahwa laporan keuangan haruslah mencerminkan keadaan perusahaan yang sebenarnya pada kurun waktu tertentu. Salah satu bentuk informasi akuntansi untuk mengetahui penilaian kinerja keuangan perusahaan maka dapat dilakukan dengan melakukan analisis dengan menggunakan rasiorasio keuangan untuk periode tahun-tahun tertentu dengan berdasarkan pada laporan keuangan perusahaan.

Rasio keuangan adalah angka yang diperoleh dari perbandingan dari satu pos laporan keuangan khususnya memperhatikan pada penghitungan rasio keuangan agar dapat mengevaluasi keadaan pada masa lalu, sekarang dan proyeksi hasil di masa datang. (Harahap, 2007).

Penilaian kinerja perusahaan dapat dilihat dari faktor keuangan yang didalamnya terdapat analisis berupa rasio keuangan. Salah satu hal mendasar yang digunakan untuk menganalisa kinerja perusahaan yaitu profit. Sekuat apapun struktur modal suatu bisnis, tidak akan ada artinya jika tidak bisa menghasilkan keuntungan. Hal ini diperoleh melalui investasi yang ditanamkan perusahaan, investasi ini banyak berbentuk aset, sehingga aset dapat menjelaskan seberapa besar perusahaan memperoleh labanya. Perbandingan antara aset dana laba ini dapat terlihat dalam rasio Return On Asset (ROA).

Biaya merupakan unsur utama yang harus dikorbankan demi kelancaran perusahaan dalam rangka menghasilkan laba yang merupa- kan tujuan utama perusahaan. Dalam pelaksanaannya memerlukan perhatian yang sangat serius selain karena biaya juga merupakan unsur pengurangan yang persentasinya cukup besar dalam hubungannya dalam pencarian laba bersih. salah satu unsur yang terkandung didalamnya, yaitu biaya merupakan pengorbanan sumber ekonomi berupa kas atau ekuivalennya, yang dapat diukur dalam satuan moneter uang, merupakan hal yang terjadi atau potensial akan terjadi dan pengorbanan tersebut.

Istilah operasional sering digunakan dalam suatu organisasi perusahaan yang menghasilkan keluaran output, baik yang berupa barang dan jasa. Secara umum operasional diartikan sebagai suatu usaha, kegiatan atau proses mentransformasikan masukan (input) menjadi hasil keluaran (output). Dalam pengertian yang bersifat umum ini penggunaan cukup luas, sehingga mencakup keluaran (output) yang berupa barang dan jasa. Jadi dalam pengertian produksi dan operasional tercakup setiap proses yang mengubah masukan (input) dan menggunakan sumber daya untuk menghasilkan keluaran (output) yang berupa barang atau jasa.

Menurut Syahrul dan Nizar (2005) mendefinisikan "Biaya operasional adalah biayabiaya yang berkaitan dengan kegiatan-kegiatan administratif dan penjualan dari suatu perusahaan. Disebut juga non manufacturing expense. Merupakan biaya periode yang berkaitan dengan waktu, bukan dengan produk. Biaya ini dibagi atas biaya penjualan dan biaya administrasi umum". Sedangkan menurut Jopie Jusuf (2008) berpendapat "Biaya operasi atau operating expenses merupakan biaya-biaya yang langsung maupun tidak langsung berhubungan dengan produk perusahaan serta aktivitas perusahaan sehari-hari".

Dengan mengetahui rasio profitabilitas yang dimiliki koperasi, maka koperasi dapat memonitor perkembangannya dari waktu ke waktu. Return On Asset (ROA) berfungsi untuk mengukur tingkat kinerja perusahaan dalam memperoleh laba yang optimal. Tersedianya modal kerja yang cukup sangat penting bagi suatu perusahaan karena dengan modal kerja yang cukup memungkinkan bagi perusahaan untuk beroperasi se-ekonomis mungkin dan perusahaan tidak mengalami kesulitan dalam 
menghadapi bahaya-bahaya yang mungkin timbul karena adanya krisis keuangan.

Dari perkembangan rentabilitas/profitabilitas yang diukur dengan ROA, memperlihatkan bahwa ada kemampuan perolehan laba yang naik turun. Hal ini menunjukan bahwa terdapat pengelolaan yang kurang baik tentang bagaimana koperasi membayar kewajibannya baik itu hutang lancar, hutang jangka pendek maupun modal kerjanya.

Kelangsungan hidup perusahaan dipengaruhi oleh banyak hal, salah satunya adalah profitabilitas. Rasio profitabilitas adalah salah satu rasio keuangan yang dapat digunakan untuk mengukur berhasil tidaknya keputusan strategi, operasi dan juga pembiayaan yang diambil manajemen. Menurut Brigham dan Houston, (2006:107), "Profitabilitas adalah hasil akhir dari sejumlah kebijakan dan keputusan yang dilakukan oleh perusahaan". Rasio Profitabilitas mengukur efektivitas manajemen berdasarkan hasil pengambilan yang dihasilkan dari penjualan dan investasi.

PTGemilang Abadi merupakan perusahaan manufaktur yang bergerak dalam industri logam besi dengan intensitas persaingan yang ketat dituntut dapat memperluas pangsa pasar mengingat persaingan semakin tajam terlebih daerah pemasarannya lebih banyak bersinggungan area dengan wilayah pemasaran perusahaan competitor.

Seiring dengan inovasi penggunaan produk serta makin terbatasnya suplai bahan ba$\mathrm{ku}$ dan penjunjang terutama penggunaan disektor infrastruktur dan sektor konstruksi, maka semua produsen mengalihkan perhatiannya pada sektor ini atau dikenal dengan sektor residensial. Melihat dari pangsa pasar yang dimiliki oleh Perusahaan, sebenarnya peluang untuk memperoleh prift margin yang maksimal selalu terbuka, dengan demikian perusahaan dalam menjalankan operasinya selalu diarahkan pada pencapaian tujuan yang telah ditetapkan. Tujuan pokok dari PT Gemilang Abadi adalah memperoleh keuntungan yang maksimal yang dilanjutkan dengan pengembangan usaha.

Keuntungan ini sangat penting bagi perusahaan karena dapat mencerminkan keberhasilan dan menjaga kelangsungan hidup perusahaan. Biaya operasional yang terjadi pada PT Gemilang Abadi terdiri dari pertama, biaya operasional langsung yang merupakan biaya-biaya yang dikeluarkan perusahaan untuk melaksanakan kegiatan operasional secara langsung. Kedua, biaya operasional tidak langsung merupakan biaya-biaya yang dikeluarkan oleh perusahaan untuk mengkoordinasikan kegiatan operasional. Dalam hal ini, pengendalian biaya operasional PT Gemilang Abadi perlu dilakukan agar biaya operasional digunakan seefisien mungkin dan pendapatan perusahaan dapat ditingkatkan.

Return On Assets (ROA) merupakan rasio yang mengukur kemampuan manajemen perusahaan yang memperoleh laba secara keseluruhan. ROA dianggap penting bagi perusahaan karena digunakan untuk mengukur efektivitas perusahaan di dalam menghasilkan keuntungan. ROA merupakan rasio antara laba sebelum pajak terhadap total aset. Semakin besar ROA suatu perusahaan, semakin besar pula tingkat keuntungan yang dicapai perusahaan tersebut, dan semakin baik posisi perusahaan tersebut dari segi penggunaan aset. Return On Assets (ROA) dipilih sebagai variabel dikarenakan rasio tersebut menggambarkan kemampuan perusahaan dalam menghasilkan laba. Oleh karena itu, dalam penelitian ini ROA digunakan sebagai ukuran kinerja perusahaan.

Dalam pengeluaran biaya operasional diharapkan perusahaan dapat menggunakan secara efisien, sehingga perusahaan dapat mencapai laba yang optimal. Namun permasalahan yang sering terjadi pada perusahaan adalah mengenai besarnya biaya yang dikeluarkan untuk memenuhi aktivitas operasional perusahaan yang tidak disertai dengan kenaikan profitabilitas. Jika dalam perusahaan terjadi penurunan atau kenaikan biaya operasional, maka perusahaan mengalami kendala dalam pencapaian laba yang maksimal sehingga berakibat pada penurunan profitabilitas perusahaan.

Biaya operasional tentunya mempengaruhi laba yang ingin dicapai oleh suatu perusahaan berdasarkan penjualan jasa atau penyaluran dan penempatan tenaga kerja baik lokal maupun ke luar negeri yang dilakukan dan biaya operasional yang dikeluarkan oleh perusaaan dalam melakukan kegiatan perusahaan.

Mengingat pentingnya perencanaan dan pengawaasan biaya operasional dalam suatu perusahaan maka penulis tertaik untuk membahasnya lebih lanjut. Sementara yang menjadi obyek penelitian adalah PT Gemilang 
Abadi. Dengan demikian penulis tertarik untuk memilih judul: "Pengaruh Biaya Operasional Terhadap Profitabilitas Pada PT Gemilang Abadi".

\section{Pembatasan Masalah}

Dengan keterbatasan peneliti dan agar lebih dimengerti serta memudahkan maka penelitian ini penulis memberikan batasan-batasan untuk memfokuskan permasalahan yang akan diteliti, yaitu mengenai biaya operasional dan profitabilitas pada PT Gemilang Abadi dengan data laporan keuangan periode tahun 200132017.

\section{Perumusan Masalah}

Berdasarkan identifikasi dan pembatasan masalah di atas, maka untuk mencegah terjadinya kerancuan dalam pembahasan, perlu penulis berikan suatu perumusan masalah sebagai berikut :

1. Bagaimana biaya operasional pada PT Gemilang Abadi.

2. Bagaimana pencapaian profitabilitas pada PT Gemilang Abadi.

3. Bagaimana pengaruh antara biaya operasional terhadap profitabilitas pada PT Gemilang Abadi

\section{Tujuan Penelitian}

Adapun tujuan penelitian ini adalah:

1. Untuk mengetahui biaya operasional pada PT Gemilang Abadi.

2. Untukmengetahuipencapaian profitabilitas pada PT Gemilang Abadi.

3. Untuk mengetahui pengaruh antara biaya operasional terhadap profitabilitas pada PT Gemilang Abadi

\section{Tinjauan Teoritik}

\section{Manajemen}

Pengertian Manajemen menurut Robbin (2007 adalah" Manajemen merupakan proses pengkoordinasian kegiatan-kegiatan pekerjaan sehingga pekerjaan tersebut terselesaikan secara efisien dan efektif dengan dan melalui orang lain".

Sedangkan menurut Griffin (2003) "Manajemen merupakan suatu rangkaian aktivitas yang diarahkan pada sumber-sumber daya organisasi (manusia, financial, fisik, dan informasi) untuk mencapai tujuan organisasi dengan cara yang efektif dan efisien".

Dari kedua pendapat tersebut diatas, maka manajemen merupakan proses pengoordinasian rangkaian aktivitas diantaranya perencanaan dan pengambilan keputusan, pengorganisasian, kepemimpinan, dan pengendalian yang diarahkan pada sumber daya organisasi untuk mencapai tujuan organisasi secara efisien dan efektif dengan dan melalui orang lain.

\section{Manajemen Keuangan}

Menurut Horne dan Wachowichz, (2005), mengemukakan "Definisi manajemen keuangan adalah segala aktivitas yang berhubungan dengan perolehan, pendanaan, dan manajemen aktiva dengan beberapa tujuan umum sebagai latar belakangnya”. Sedangkan menurut Darsono, (2006:1) berpendapat bahwa "Definisi manajemen keuangan adalah aktivitas pemilik dan manajemen perusahaan untuk memperoleh sumber modal yang semurahmurahnya dan menggunakannya seefektif, seefesien dan seproduktif mungkin untuk memperoleh laba".

Sedangkan pendapat lain dikemukakan oleh Martono dan Agus Harjito (2010) yang mendefinisikan "Manajemen keuangan (financial management) merupakan segala aktivitas perusahaan yang berhubungan dengan bagaimana memperoleh dana, menggunakan dana, dan mengelola asset sesuai tujuan perusahaan secara menyeluruh".

Pendapat lain dikemukakan oleh Sutrisno (2003) yang mengartikan sebagai berikut "Manajemen keuangan adalah sebagai semua aktivitas perusahaan dengan usaha-usaha mendapatkan dana perusahaan dengan biaya yang murah serta usaha untuk menggunakan dan mengalokasikan dana tersebut secara efisien".

Dari beberapa pendapat ahli tersebut diatas, dapat ditarik kesimpulan bahwa Manajemen keuangan adalah suatu kegiatan perencanaan, penganggaran, pemeriksaan, pengelolaan, pengendalian, pencarian dan penyimpanan dana yang dimiliki oleh perusahaan.

\section{Biaya Operasional}

Menurut Syahrul dan Nizar (2005) berpendapat "Biaya operasional adalah biayabiaya yang berkaitan dengan kegiatan-kegiatan administratif dan penjualan dari suatu perusahaan atau disebut juga non manufacturing 
expense, yang merupakan biaya periode yang berkaitan dengan waktu, bukan dengan produk. Biaya ini dibagi atas biaya penjualan dan biaya administrasi umum".

Sedangkan menurut Carter dan Usry (2004) mendefenisikan "Biaya operasional sebagai pengeluaran, pengorbanan untuk memperoleh manfaat, sehingga dalam akuntansi keuangan, pengeluaran atau pengorbanan pada saat akuisisi diwakili oleh penyusutan saat ini atau dimasa yang akan datang dalam bentuk kas atau aktiva lain".

Pendapat lain dikemukakan oleh Jopie Jusuf (2008) mendefinisikan "Biaya operasional adalah biaya-biaya yang tidak berhubungan langsung dengan produk perusahaan tetapi berkaitan dengan aktivitas operasional perusahaan sehari-hari".

Dari ketiga pendapat ahli tersebut diatas, dapat disimpulkan biaya operasional adalah pengeluaran yang berhubungan dengan operasi, yaitu semua pengeluaran yang langsung digunakan untuk produksi atau pembelian barang yang diperdagangkan termasuk biaya umum, penjualan, administrasi, dan bunga pinjaman.

\section{Profitabilitas}

Kemampuan suatu perusahaan dalam memperoleh keuntungan atau laba dapat dilihat dari perolehan persentase Profitabilitas yang dicapainya. Profitabilitas merupakan salah satu alat ukur kinerja keuangan perusahaan berdasarkan kemampuan perusahaan tersebut dalam memperoleh laba. Profitabilitas ini umumnya selalu diukur dengan membandingkan laba yang diperoleh perusahaan dengan sejumlah perkiraan yang menjadi tolak ukur keberhasilan perusahaan seperti jumlah aset perusahaan maupun penjualan investasi, sehingga dapat diketahui efektifitas pengelolaan keuangan dan aset oleh perusahaan.

Bila pendapatan melebihi biaya, maka selisihnya adalah laba atau keuntungan, dilain pihak bila biaya melebihi pendapatan maka selisihnya merupakan kerugian. Dari uraian di atas dapat disimpulkan laba adalah selisih positif antara pendapatan dan biaya. Semakin tinggi penjualan barang atau jasa, maka laba yang diperoleh akan meningkat dan profitabilitas juga meningkat pula. Namun demikian, semakin rendah penjualan barang atau jasa, maka laba atau keuntungan yang diperoleh akan turun dan profitabilitas juga akan ikut turun.

Menurut pendapat Riyanto (2007) mendefinisikan "Profitabilitas adalah kemampuan suatu perusahaan untuk menghasilkan laba selama suatu periode tertentu". Sedangkan menurut Sutojo (2008) "Operasi bisnis perusahaan dapat dikatakan berhasil apabila dari masa ke masa dapat mengumpulkan keuntungan secara memadai". Lain halnya dengan pendapat Ridwan dan Inge (2003) yang mendefinisikan "Profitabilitas adalah rasio untuk mengukur efektivitas manajemen secara keseluruhan yang ditujukan oleh besar kecilnya tingkat keuntungan yang diperoleh dalam hubungannya dengan penjualan dan investasi”.

Dari pengertian beberapa pendapat tersebut di atas, dapat disimpulkan bahwa Profitabilitas adalah kemampuan sebuah perusahaan dalam memperoleh atau menghasilkan laba atau keuntungan dalam hubungannya dengan penjualan dan investasi dalam suatu periode tertentu.

\section{Hipotesis Penelitian}

Menurut Sugiyono (2014) berpendapat "Hipotesis adalah jawaban sementara terhadap rumusan masalah. Karena sifatnya masih sementara, maka perlu dibuktikan kebenarannya melalui data empirik yang terkumpul".

Adapun Hipotesis yang penulis ajukan adalah sebagai berikut:

$\mathrm{H}^{0}$ : Tidak terdapat pengaruh positif dan signifikan antara Biaya operasional terhadap profitabilitas.

$\mathrm{H}_{1}$ : Terdapat pengaruh positif dan signifikan antara Biaya operasional terhadap profitabilitas.

\section{METODOLOGI PENELITIAN Populasi Dan Sampel}

Adapun populasi dalam penelitian ini adalah data berupa laporan keuangan pada PT Gemilang Abadi. Teknik yang digunakan dalam penarikan sampel menggunakan teknik non probability sampling. Non probability sampling. Adapun yang dijadikan sampel dalam penelitian ini adalah Laporan neraca dan Laba/Rugi PT Gemilang Abadi periode 2013-2017 yang di rangkum berdasarkan kebutuhan penulis. 


\section{Variabel Penelitian}

Dalam penelitian ini terdapat tiga variabel, yaitu variabel independen, variabel dependen dan variabel moderating, seperti berikut:

1. Variabel bebas (independent variable) Variabel bebas yang dalam hubungannya dengan variabel lain bertindak sebagai penyebab atau yang mempengaruhi variabel dependen. Pada penelitian ini sebagai variabel independen yakni Biaya operasional. Variabel independen sering disebut sebagai predictor yang dilambangkan dengan $\mathrm{X}$.

2. Variabel terikat (dependent variable) Variabel yang tergantung dengan variabel lain, atau variabel yang dapat dipengaruhi oleh variabel lain. Sering disebut variabel respon di mana dalam penelitian ini adalah profitabilitas yang dilambangkan dengan $\mathrm{Y}$.

\section{Definisi Operasional Variabel}

Pengertian operasional variabel ini kemudian diuraikan menjadi indikator empiris yang meliputi :

\section{Biaya Operasional $(\mathrm{X})$}

Biaya operasional adalah biaya yang terjadi dalam kaitannya dengan operasi (operation cost) yang dilakukan oleh perusahaan untuk mendukung atau menunjang usaha perusahaan dan diukur dalam satuan uang (Jopie Yusuf, 2008:33). Dalam penelitian ini meliputi: Harga pokok penjualan, biaya pemasaran dan biaya administrasi umum.

Secara umum biaya diartikan sebagai pengeluaran biaya yang terjadi dalam kaitannya dengan operasi yang dilakukan perusahaan dan diukur dalam satuan uang dimana biaya operasional sering disebut sebagai operation cost. Menurut Mulyadi, (2002) berpendapat bahwa menurut fungsi pokok dalam perusahaan, biaya dapat digolongkan menjadi 3 yaitu :

a. Biaya Produksi atau dalam perusahaan ini adalah biaya-biaya yang terjadi untuk mengolah menyiapkan material menjadi siap pakai.

b. Biaya Pemasaran adalah merupakan biaya yang terjadi untuk melaksanakan kegiatan pemasaran produk atau jasa. Contohnya biaya iklan, biaya promosi, dan lain-lain.

c. Biaya administrasi dan umum adalah merupakan biaya-biaya untuk mengkoordinasi kegiatan produksi dan pemasaran produk. Contohnya biaya gaji karyawan bagian akuntansi, keuangan, personalia, dan lain-lain.

\section{Profitabilitas $(\mathrm{Y})$}

Profitabilitas merupakan kemampuan suatu perusahaan dalam menghasilkan laba selama periode tertentu yang dinyatakan dalam prosentase (Riyanto, 2009:38). Rentabilitas diukur dengan kesuksesan perusahaan dan kemampuan menggunakan aktiva yang produktif.

Menurut Bambang Riyanto (2007:336) menyatakan bahwa, rumus untuk menentukan Return on Assets (ROA) adalah sebagai berikut:

$$
\text { ROA }=\frac{\text { LABA SEBELUM PAJAK }}{\text { TOTAL MODAL ASSETS }} \times 100 \%
$$

Biaya-biaya operasi merupakan biaya-biaya anggaran untuk melaksanakan proses operasi. Hal tersebut ada apabila ada target seperti peningkatan rentabilitas (return on assets). Upaya peningkatan rentabilitas dipengaruhi oleh biaya operasi yang mana berfungsi sebagai biaya anggaran untuk proses pencapaian target tujuan yang telah ditetapkan. Biaya operasional yang dimaksud dalam hal ini adalah rasio tentang perbandingan antara harga pokok barang terjual ditambah biaya operasi dengan penjualan. Sedangkan profitabilitas yang dipergunakan adalah rasio laba operasi terhadap total aktiva. Biaya operasional digunakan sebagai alat untuk meningkatkan rentabilitas (return on assets) yang diupayakan oleh perusahaan. Return On Assets atau ROA untuk Singkatnya, adalah ukuran bagaimana sebuah perusahaan memperoleh keuntungan bila dibandingkan dengan total asset. Penghasilan tahunan tersebut hanya dibagi dengan seluruh aset perusahaan yang hasilnya ditunjukkan sebagai persentase.

\section{Metode Pengumpulan Data}

\section{Observasi}

Metode ini dipergunakan untuk mendapatkan data primer kuantitatif, dilakukan dengan cara penulis langsung mendatangi perusahaan pada bagian keuangan guna mendapatkan data berupa laporan keuangan perusahaan yaitu laporan neraca dan laporan rugi/laba periode tahun 20013-2017, serta untuk memperoleh gambaran obyek yang diteliti yang nantinya 
akan dapat digunakan untuk tambahan dalam melakukan analisis.

\section{Wawancara}

Dalam penelitian ini untuk mendapatkan dataprimerkualitatifdenganmetodewawancara, penulis datang ke kantor PT Gemilang Abadi. Untuk melakukan studi pendahuluan dengan teknik wawancara langsung dengan pihak yang berkompeten dalam perusahaan, mengenai obyek yang diteliti.

\section{Studi Pustaka}

Untuk medapatkan data sekunder penulis melakukan dengan cara penelahaan terhadap literature-literature berupa buku-buku kuliah dan data yang diperoleh dalam bentuk yang sudah jadi, sudah diolah oleh pihak lain biasaya dalam bentuk publikasi serta bahan-bahan yang berhubungan dengan masalah yang berkaitan dengan penelitian ini.

\section{Metode Analisis Data}

\section{Analisis Deskriptif}

Analisis dilakukan dengan menyajikan data, menganalisis melalui perhitungan serta menjelaskan perkembangan setiap tahun atas fenomena keuangan yang terjadi kemudian pengolahan data dengan statistik guna menguji hipotesis yang telah ditetapkan.

\section{Analisis Verivikatif}

Analisis kuatitatif adalah penelitian yang telah dilakukan untuk menilai kondisi dari nilai pengaruh, signifikansi pengaruh. Menurut Sugiyono (2014) "Metode verifikatif merupakan penelitian yang bertujuan untuk mengetahui hubungan antara 2 (dua) variabel atau lebih. Dengan demikian dari hasil dari analisis ini akan memberikan jawaban awal dari kalimat tanya pada perumusan masalah : bagaimana pengaruh variabel independen terhadap variabel dependen secara parsial maupun secara simultan berdasarkan data yang ada. Dalam penelitian ini data yang dimaksud adalah data berupa laporan keuangan dari PT Gemilang Abadi periode 20013-2017 yang sudah dibuat data panel. Adapun tahapan analisis yang dilakukan meliputi:

\section{a. Analisis Regresi Lnier Sederhana}

Analisis regresi liner sederhana ini dalam penelitian ini dimaksudkan untuk menganalisis pengaruh antara variable biaya operasional terhadap profitabilitas pada PT. Gemilang Abadi.

Jika variabel bebas mengalami perubahan naik atau turun, maka bagaimana dengan variabel terikatnya, apakah mengalami kenaikan apa penurunan.

\section{b. Analisis Koefisien Korelasi}

Analisis koefisien korelasi ini bertujuan untuk mengetahui tingkat keterhubungan atau tingkat pengaruh pengaruh antara variabel independen terhadap variabel dependennya. Adapun menurut Sugiyono (2014) untuk menginterpretasikan hasil penelitian korelasi, maka dapat berpedoman pada ketentuan yang tertera pada tabel berikut ini:

\begin{tabular}{|c|c|}
\hline \multicolumn{2}{|c|}{ Tabel 1. Pedoman Untuk Interpretasi Koefisien Korelasi } \\
\hline Interval Korelasi & \begin{tabular}{c} 
Tingkat Hubungan \\
\hline $0,000-0,199$
\end{tabular} \\
\hline $0,200-0,399$ & Sangat rendah \\
\hline $0,400-0,599$ & Rendah \\
\hline $0,600-0,799$ & Sedang \\
\hline $0,800-1,000$ & Kuat \\
\hline
\end{tabular}

\section{c. Analisis Koefisien Determinasi}

Dalam penelitian ini untuk mengetahui berapa besar persentase pengaruh antara variabel independen terhadapvariabeldependen. Koefisien Determinasi $(\mathrm{Kd})$ merupakan besaran nol negatif. Besarnya nilai koefisien determinasi adalah antar nol sampai dengan satu. Koefisien determinasi bernilai nol berarti tidak ada hubungan antara variabel $\mathrm{X}$ (bebas) dengan variabel $\mathrm{Y}$ (terikat). Sebaliknya nilai koefisien determinasi 1 berarti suatu kecocokan yang sempurna dari ketepatan perkiraan model. Sedangkan untuk mengetahui besarnya kontribusi dari variabel $(\mathrm{X})$ terhadap nilai variabel $(\mathrm{Y})$.

\section{d. Pengujian Hipotesis (Uji t)}

Menurut Sugiyono (2014) pengertian hipotesis adalah "Hipotesis merupakan jawaban sementara terhadap rumusan masalah penelitian, oleh karena itu rumusan masalah penelitian biasanya disusun dalam bentuk kalimat pertanyaan. " Dengan demikian hipotesis penelitian dapat diartikan sebagai jawaban yang bersifat sementara terhadap masalah penelitian, sampai terbukti melalui data yang terkumpul dan harus diuji secara empiris. Dalam penelitian ini uji hipotesis diperlukan untuk 
menguji apakah biaya operasional berpengaruh terhadap profitabilitas.

Tingkat signifikansi yang dipilih dalam penelitian ini adalah 0,05 atau (5\%) artinya kemungkinan besar dari hasil penarikan kesimpulan mempunyai probabilitas $95 \%$ atau toleransi kesalahan sebesar 5\%. Sedangkan untuk menguji diterima atau ditolaknya suatu hipotesis, maka dilakukan dengan cara uji t. Hubungan variabel independen dengan variabel dependen, akan diuji dengan uji t yaitu dengan membandingkan $\mathrm{t}_{\text {tabel }}$ dengan $\mathrm{t}_{\text {hitung }}$.

\section{HASIL ANALISIS DAN PEMBAHASAN}

\section{Analisis Deskriptif}

\section{a. Perkembangan Biaya Operasional}

Analisis dilakukan dengan menyajikan data, menganalisis melalui perhitungan, penjelasan perkembangan setiap variabel dan pengolahan data dengan statistik guna menguji hipotesis.

Biaya operasional sudah barang tentu dianggarkan untuk menunjang pencapaian penjualan disektor jasa yang dihasilkan oleh PT Gemilang Abadi secara maksimal sebagai hasil dari upaya untuk mengoptimalkan menunjukkan hasil yang terus meningkat daritahun ke tahun, tentu hal ini sejalan dengan tujuan perusahaan untuk tetap mempertahankan dan meningkatkan profitabilitas (laba) agar perusahaan terus dapat memaksimalkan laba sehingga eksistensi kelangsungan usaha dapat dijaga dengan baik. Untuk mengetahui seberapa besar perubahan pencapaian kenaikan profitabilitas (laba) yang diperoleh perusahaan setiap tahunnya, berikut ini perkembangan biaya operasional pada PT Gemilang Abadi selama 5 (lima) tahun yaitu tahun 2013-2017 dalam tabel, dan analisanya sebagai berikut:

\begin{tabular}{|c|c|c|c|}
\hline \multicolumn{4}{|c|}{$\begin{array}{c}\text { Tabel 2. Perkembangan Besarnya } \\
\text { Biaya Operasional Tahun 2013-2017 (Dalam Rupiah) }\end{array}$} \\
\cline { 3 - 4 } Tahun & \multirow{2}{*}{ Biaya Operasional } & Pertumbuhan \\
\cline { 3 - 4 } & & (Rupiah) & (\%) \\
\hline 2013 & 8.548 .784 .553 & - & - \\
\hline 2014 & 7.125 .514 .453 & $(1.423 .270 .100)$ & $(16,65 \%)$ \\
\hline 2015 & 8.920 .022 .175 & 1.794 .507 .722 & $25,18 \%$ \\
\hline 2016 & 8.762 .891 .535 & $(157.130 .640)$ & $(1,76 \%)$ \\
\hline 2017 & 8.867 .594 .334 & 104.702 .799 & $1,19 \%$ \\
\hline \multicolumn{4}{|c|}{ Sumber: Data Primer diolah } \\
\hline
\end{tabular}

Berdasarkan data pada tabel di atas, biaya operasional yang dikeluarkan setiap tahunnya berfluktuatif. Biaya operasional pada tahun 2013 sebesar Rp.8.548.784.553, tahun 2014 biaya operasional menurun menjadi Rp.7.125.514.453, tahun 2015 dan 2013 ada kenaikan keduanya, sedangkan ditahun terakhir 2017 ada sedikit kenaikan biaya operasional menjadi Rp.8.867.594.334, biaya operasional mengalami kenaikan sebesar Rp.104.702.799 atau $1,19 \%$, hal ini disebabkan karena biaya marketing mengalami kenaikan dengan kunjungan dan kegiatan promosi sehingga biaya operasional juga meningkat.

\section{b. Perkembangan Profitabilitas}

Profitabilitas (laba) yang terus meningkat merupakan tujuan perusahaan dalam upaya terus meningkatkan laba. Berikut ini perkembangan Profitabilitas (laba) pada PT Gemilang Abadi selama 5 (lima) tahun 2013-2017 dalam tabel dan hasil analisanya:

\begin{tabular}{|c|c|c|c|}
\hline \multirow{4}{*}{ Tabel 3. Perkembangan Profitabilitas } \\
\hline \multirow{2}{*}{ Tahun } & \multirow{2}{*}{ Profitabilitas } & \multicolumn{2}{|c|}{ Pertumbuhan } \\
\cline { 3 - 4 } & & Selisih tahun sebelumnya & (\%) \\
\hline 2013 & 8,51 & - & - \\
\hline 2014 & 7,11 & $(1,40)$ & $17,42 \%$ \\
\hline 2015 & 8,35 & 1,24 & $(1,55 \%)$ \\
\hline 2016 & 8,23 & $(0,13)$ & $(2,62 \%)$ \\
\hline 2017 & 8,01 & $(0,22)$ & \multicolumn{2}{c}{ Sumber: Data Primer diolah } \\
\hline \multicolumn{2}{|r|}{}
\end{tabular}

Berdasarkan tabel di atas, menunjukkan bahwa perolehan laba (profitabilitas) yang terjadi pada PT Gemilang Abadi setiap tahunnya berfluktuasi. Profitabilitas pada tahun 2013 sebesar 8,51\%, tahun 2014 menurun menjadi $7,11 \%$, tahun 2015 mengalami peningkatan $1,24 \%$ menjadi sebesar $8,35 \%$ dari tahun sebelumnya, namun pada tahun 2016 ada sedikit menurunan $0,13 \%$ menjadi $8,23 \%$ dan pada tahun 2017 kembali mengalami penurunan $0,22 \%$ menjadi $8,01 \%$.

\section{Analisis Verifikatif}

Dalam mengukur Pengaruh Biaya Operasional Terhadap Profitabilitas, dihitung menggunakan analisa kuantitatif sebagai berikut: 


\begin{tabular}{|c|c|c|c|c|c|}
\hline \multicolumn{6}{|c|}{$\begin{array}{l}\text { Tabel 4. Biaya Operasional Terhadap Profitabilitas } \\
\text { Tahun 2013-2017 }\end{array}$} \\
\hline Thun & $\begin{array}{l}\text { Biaja Operasional } \\
\text { (Dalam Juta) } \\
(X)\end{array}$ & $\begin{array}{l}\text { Profitabilithas } \\
\text { (I) }\end{array}$ & $X Y$ & $x^{2}$ & $y^{2}$ \\
\hline 2010 & $8,548.785$ & 8.51 & $72,783.33$ & $73,081,717.33$ & 72.48616 \\
\hline 2011 & $7,125.514$ & 7.12 & $50,702.83$ & $50,772,956.22$ & 50.63281 \\
\hline 2012 & $8,920.022$ & 8.36 & $74,528.23$ & $79,566,795.60$ & 69.80873 \\
\hline 2013 & $8,762.892$ & 8.23 & $72,083.02$ & $76,788,268.05$ & 67.66609 \\
\hline 2014 & $8,867.594$ & 8.01 & $71,029.70$ & $78,634,229.27$ & 64.16059 \\
\hline$\Sigma=5$ & 42.224 .807 & 40.22 & $341,127.12$ & $358,843,966.48$ & 324.75439 \\
\hline \multicolumn{6}{|c|}{ Sumber: Data Primer diolah } \\
\hline
\end{tabular}

Berdasarkan perhitungan pada tabel di atas maka diperoleh:

$$
\begin{aligned}
& \sum \mathrm{X}: 42.224 .807 \\
& \sum X^{2}: 358.843 .966,48 \\
& \sum \mathrm{Y}: 40.22 \\
& \sum Y^{2}: 324.75439 \\
& \sum X Y \text { : 341,127.12 }
\end{aligned}
$$

Setelah diperoleh total atau sigma dari perhitungan di atas, maka analisis dilanjutkan pada uji statistik yang dimaksudkan untuk menunjukkan hasil keberpengaruhan antara variabel independen terhadap variabel dependennya. Analisis yang dipakai adalah regresi linier sederhana, koefisien korelasi, koefisien determinasi dan uji hipotesis. Adapun hasil analisis dalam penelitian ini sebagai berikut:

\section{Analisis Regresi Linier Sederhana}

Uji regresi linier sederhana ini dimaksudkan untuk mengetahui seberapa besar pengaruh variabel biaya operasional terhadap profitabilitas. Adapun hasil analisis regresi linier sederhana sebagai berikut:

$$
\begin{aligned}
& a=\frac{\left(\sum Y \cdot \sum X^{2}\right)-\left(\sum X \cdot \sum X Y\right)}{\mathrm{n} \sum X^{2}-\left(\sum X\right)^{2}} \\
& =\frac{14.432 .950 .830,12-(42.224,81 \times 341.127,12)}{1.794 .219 .832,41-1.782 .834 .330,41} \\
& =\frac{14.432 .950 .830,12-14.404 .026 .814,26}{11.285 .502}
\end{aligned}
$$

\begin{tabular}{|c|c|c|c|c|c|}
\hline \multicolumn{6}{|c|}{$\begin{array}{c}\text { Tabel 5. Hasil Uji Regresi Linier Sederhana } \\
\text { Antara Biaya Operasional (X) Terhadap Profitabilitas }\end{array}$} \\
\hline \multicolumn{6}{|c|}{ Coefficients $^{\mathrm{a}}$} \\
\hline \multirow[b]{2}{*}{ Model } & \multicolumn{2}{|c|}{$\begin{array}{l}\text { Unstandardized } \\
\text { Coefficients }\end{array}$} & \multicolumn{3}{|c|}{ Standardized Coefficients } \\
\hline & B & Std. Error & Beta & $t$ & Sig. \\
\hline 1 (Constant) & 2.574 & 1.657 & & 1.554 & .218 \\
\hline Biaya Operasional $(X)$ & 0.0001 & .000 & .886 & 3.313 & .045 \\
\hline \multicolumn{6}{|c|}{ Sumber : Data Primer diolah } \\
\hline
\end{tabular}

$$
\begin{aligned}
& =\frac{28.924 \cdot 015,86}{11.285 .502} \\
& a=2,574 \\
& b=\frac{n \sum X Y-\sum X \sum Y}{n \sum X^{2}-\left(\sum X\right)^{2}}
\end{aligned}
$$

$$
\begin{aligned}
& =\frac{(5 \times 341.127,12)-(42.224,81 \times 40.221)}{(5 \times 358.843 .966,48)-(4.117,70)^{2}} \\
& =\frac{1.705 .635,60-1.698 .310,74}{1.794 .219 .832,41-1.782 .934 .330,41} \\
& =\frac{7.324,85}{11.285 .502} \\
& b=0,0001
\end{aligned}
$$

Berdasarkan perhitungan regresi linier sederhana dengan manual di atas, juga dilakukan dengan menggunakan program IBM SPSS (Statistical Program for Social Science) diperoleh hasil sebagai berikut:

Berdasarkan hasil perhitungan regresi linier sederhana tersebut diatas, maka dapat diperoleh persamaan regresi linier sederhananya yaitu $Y$ $=a+b x$, diketahui $\mathbf{Y}=\mathbf{2 , 5 7 4 + \mathbf { 0 , 0 0 1 x }}$

Dari persamaan tersebut terlihat bahwa biaya operasional mempunyai pengaruh yang positif terhadap profitabilitas. Hubungan positif itu dapat dilihat nilai b bernilai positif pada persamaan tersebut, maka menunjukkan hubungan yang searah. Hubungan positif tersebut menunjukkan bahwa profitabilitas akan sejalan dengan perubahan jumlah biaya operasional yang telah dikeluarkan oleh perusahaan. Artinya apabila terjadi kenaikan biaya operasional maka profitabilitas PT Gemilang Abadi akan ikut mengalami kenaikan, dan sebaliknya jika terjadi penurunan biaya operasional maka akan hal tersebut akan menurunkan profitabilitas pada PT Gemilang Abadi. Dari persamaan di atas maka dapat dijelaskan juga sebagai berikut:

a. Nilai koefisien regresi bernilai positif, hal ini menyatakan bahwa adanya hubungan yang positif antara biaya operasional dengan profitabilitas. Artinya peningkatan biaya operasional akan meningkatkan profitabilitas. Sebaliknya, penurunan bia- 
ya operasional akan menurunkan profitabilitas perusahaan.

b. Nilai konstanta sebesar 2,574 menyatakan bahwa jika tidak ada biaya operasional, maka profitabilitas adalah $0,001 \%$.

c. Nilai koefisien regresi sebesar 0,001 menyatakan bahwa setiap kenaikan biaya operasional sebesar Rp.1,00 akan menaikkan probitabilitas sebesar 0,001 . Sebaliknya jika biaya operasional turun sebesar Rp.1,00 maka profitabilitas akan mengalami penurunan sebesar 0,001

\section{Analisis Koefisien Korelasi}

Analisis koefisien korelasi (R) digunakan untuk mengetahui tingkat kekuatan hubungan atau pengaruh dari variabel bebas terhadap variabel terikat, dalam hal ini adalah variabel biaya operasional $(\mathrm{X})$ terhadap profitabilitas (Y). Adapun hasil pengolahan data dapat dijelaskan sebagai berikut:

$$
\begin{aligned}
& r=\frac{\mathrm{n} \sum \mathrm{XY}-\sum \mathrm{X} \sum \mathrm{Y}}{\sqrt{\left(\mathrm{n} \sum \mathrm{X}^{2}-\left(\sum \mathrm{X}\right)^{2}\right)\left(\mathrm{n} \sum \mathrm{Y}^{2}-\left(\sum \mathrm{Y}\right)^{2}\right)}} \\
& =\frac{5(341.127,12)-(42.224,81 \times 40.221)}{\sqrt{(5 \times 358.843 .966,48)-(1.782 .934 .330,41) \times(5 \times 324.754-1.617 .704)}} \\
& =\frac{1.705 .635,60-1.698 .310,74}{\sqrt{(1.794 .219 .832,41-1.782 .934 .330,41) \times(1.623,77 \times 1.617 .704)}} \\
& =\frac{7,325}{\sqrt{11.285 .502 \times 6.068}} \\
& =\frac{7,324,85}{\sqrt{8.275,48}} \\
& =0,886
\end{aligned}
$$

\begin{tabular}{|c|c|c|c|}
\hline \multicolumn{4}{|c|}{$\begin{array}{l}\text { Tabel 6. Hasil Uji Koefisien Korelasi } \\
\text { Pengaruh Biaya Operasional }(X) \text { Terhadap Profitabilitas }(Y)\end{array}$} \\
\hline \multicolumn{4}{|c|}{ Coefficients $^{b}$} \\
\hline & & $\operatorname{CAR}\left(X_{1}\right)$ & ROA (Y) \\
\hline \multirow{2}{*}{ Biaya Operasional $(X)$} & Pearson Correlation & 1 & $.886^{*}$ \\
\hline & Sig. (2-tailed) & & .045 \\
\hline \multirow{2}{*}{ Profitabilitas (Y) } & Pearson Correlation & $.886^{*}$ & 1 \\
\hline & Sig. (2-tailed) & .045 & \\
\hline & & Sumber & rimer diolah \\
\hline
\end{tabular}

Berdasarkan perhitungan koefisien korelasi dengan manual di atas, juga dilakukan dengan menggunakan program SPSS (Statistical Program for Social Science) diperoleh hasil sebagai berikut:

Berdasarkan hasil pada tabel di atas, diperoleh nilai koefisien korelasinya sebesar
0,885 dan bernilai positif, dan sesuai ketentuan apabila $\mathrm{r}$ mendekat ke angka 1 maka antara kedua variabel tersebut memiliki hubungan yang positif. Artinya Biaya Operasional mempunyai pengaruh yang sangat kuat positif dan signifikan terhadap Profitabilitas.

\section{Analisis Koefisien Determinasi}

Analisis koefisien deteminasi dimaksudkan untuk mengetahui kontribusi besarnya pengaruh antara variabel bebas terhadap variabel terikat, dalam hal ini adalah biaya operasional terhadap profitabilitas. Adapun hasil pengolahan data dapat dijelaskan sebagai berikut :

$$
\begin{aligned}
\mathrm{Kd} & =\mathrm{r}^{2} \times 100 \% \\
& =0,886^{2} \times 100 \% \\
& =0,783 \times 100 \% \\
& =78,5 \%
\end{aligned}
$$

Berdasarkan perhitungan koefisien determinasi dengan manual di atas, juga dilakukan dengan menggunakan program SPSS (Statistical Program for Social Science) diperoleh hasil sebagai berikut:

\begin{tabular}{|l|r|r|r|r|}
\hline \multicolumn{5}{|c|}{$\begin{array}{c}\text { Tabel 7. Hasil Uji Koefisien Determinasi } \\
\text { Pengaruh Biaya Operasional (X) Terhadap Profitabilitas (Y) }\end{array}$} \\
\hline Model & \multicolumn{1}{|c|}{ R } & R Square & Adjusted R Square & $\begin{array}{r}\text { Std. Error of } \\
\text { the Estimate }\end{array}$ \\
\hline 1 & $.886^{\circ}$ & .785 & .714 & .294 \\
\hline \multicolumn{5}{|c|}{ Sumber : Data primer diolah } \\
\hline
\end{tabular}

Berdasarkan hasil pada tabel di atas dapat dilihat bahwa nilai $R$ Square sebesar 0,783 atau $78,3 \%$. Hal ini menunjukkan bahwa pengaruh biaya operasional (X) terhadap profitabilitas adalah sebesar $78,5 \%$, sedangkan sisanya sebesar $21,5 \%$ dipengaruhi oleh faktor lain yang tidak diteliti.

\section{Pengujian Hipotesis (Uji T)}

Pengujian hipotesis menggunakan uji $t$ yaitu untuk menguji bagaimana pengaruh variabel bebas terhadap variabel terikatnya. Adapun rumusan hipotesis yang dibuat adalah: $\mathrm{H}_{0}$ : Tidak terdapat pengaruh positif dan signifikan antara Biaya operasional terhadap profitabilitas.

$\mathrm{H}_{1}$ : Terdapat pengaruh positif dan signifikan antara Biaya operasional terhadap profitabilitas.

Ketentuan untuk uji t adalah : 
$\mathrm{H}_{0}$, diterima jika $\mathrm{t}_{\text {hitung }}<\mathrm{t}_{\text {tabel }}$

$\mathrm{H}_{0}$, ditolak jika $\mathrm{t}_{\text {hitung }}>\mathrm{t}_{\text {tabel }}$

thit $=\frac{\mathrm{r} \sqrt{\mathrm{n}-2}}{\sqrt{1-r^{2}}}$

$=\frac{0,885 \sqrt{3}}{\sqrt{1-0,783}}$

$=\frac{0,885 \times 1,732}{\sqrt{0,217}}$

$=\frac{1,533}{\sqrt{0,465}}$

$=3,313$

Berdasarkan perhitungan uji hipotesis dengan manual di atas, juga dilakukan dengan menggunakan program IBM SPSS (Statistical Program for Social Science) diperoleh hasil sebagai berikut:

\begin{tabular}{|c|c|c|c|c|c|}
\hline \multicolumn{6}{|c|}{ Tabel 8. Hasil Uji Hipotesis } \\
\hline \multicolumn{6}{|c|}{ Coefficientsa } \\
\hline \multirow[b]{2}{*}{ Model } & \multicolumn{2}{|c|}{$\begin{array}{l}\text { Unstandardized } \\
\text { Coefficients }\end{array}$} & \multicolumn{3}{|c|}{ Standardized Coefficients } \\
\hline & B & Std. Error & Beta & $t$ & Sig. \\
\hline 1 (Constant) & 2.574 & 1.657 & & 1.554 & .218 \\
\hline Biaya Operasional $(X)$ & 0.0001 & .000 & .886 & 3.313 & .045 \\
\hline
\end{tabular}

Berdasarkan hasil pengolahan data di atas, diperoleh nilai $\mathrm{t}_{\text {hitung }}<\mathrm{t}_{\text {tabel }}$ atau $(3,313>3,182)$, hal itu juga diperkuat dengan signifikansi $0,045<0,000)$. Dengan demikian hipotesis $\mathrm{H}_{1}$ diterima artinya terdapat pengaruh positif dan signifikan antara biaya operasional terhadap profitabilitas.

\section{Pembahasan Hasil Penelitian}

\section{Pembahasan Deskriptif}

a. Kriteria Obyek Yang di Teliti Berdasarkan Variabel Biaya Operasional (X)

Biaya operasional dikeluarkan oleh perusahaan sepanjang tahun 2013-2017 dalam kondisi berfluktuatif. Biaya operasional pada tahun 2013 sebesar Rp.8.548.784.553, tahun 2014 biaya operasional menurun menjadi Rp.7.125.514.453, tahun 2015 dan 2013 ada kenaikan keduanya, sedangkan ditahun ter- akhir 2017 ada sedikit kenaikan biaya operasional menjadi Rp.8.867.594.334, biaya operasional mengalami kenaikan sebesar Rp.104.702.799 atau 1,19\%, hal ini disebabkan karena biaya marketing mengalami kenaikan dengan kunjungan dan kegiatan.

\section{b. Kriteria Obyek Yang di Teliti Berdasarkan Variabel Profitabilitas (Y)}

Perolehan laba (profitabilitas) yang terjadi pada PT Gemilang Abadi setiap tahunnya berfluktuasi. Profitabilitas pada tahun 2013 sebesar 8,51\%, tahun 2014 menurun menjadi 7,11\%, tahun 2015 mengalami peningkatan 1,24\% menjadi sebesar $8,35 \%$ dari tahun sebelumnya, namun pada tahun 2016 ada sedikit menurunan $0,13 \%$ menjadi $8,23 \%$ dan pada tahun 2017 kembali mengalami penurunan $0,22 \%$ menjadi $8,01 \%$.

\section{Pembahasan Verifikatif}

Pengaruh Biaya Operasional Terhadap Profitabilitas Pada PT. Gemilang Abadi

Dari hasil analisis statistik, diperoleh persa-

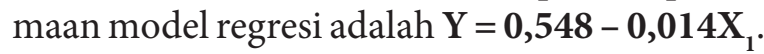
Koefisien beta memiliki nilai negatif sehingga DFL memiliki pengaruh yang negatif. Koefisien korelasi antara DFL terhadap rentabilitas adalah sebesar -0,709. Dengan demikian dapat dikatakan bahwa kedua variabel memiliki hubungan yang negatif sebesar -0,709 dengan tingkat hubungan atau pengaruh kuat. Nilai koefisien determinasi diperoleh sebesar 0,503, data tersebut mengindikasikan bahwa variabel DFL memberikan kontribusi pengaruh sebesar $50,3 \%$ terhadap rentabilitas. Uji hipotesis diperoleh nilai $\mathrm{t}_{\text {hitung }}<\mathrm{t}_{\text {tabel }}$ atau $(-2,248<2,576)$ dan signifikansi $t>0,05$ atau $(0,074>0,05)$. Dengan demikian hipotesis $\mathrm{H}_{1}$ yang penulis ajukan ditolak, hal ini menunjukkan bahwa DFL berpengaruh negatif dan siginifikan terhadap rentabilitas.

\section{KESIMPULAN, IMPLIKASI DAN SARAN Kesimpulan}

Setelah penulis menguraikan dan menganalisa tentang pengaruh biaya operasional terhadap profitabilitas pada PT Gemilang Abadi, maka penulis dapat menarik kesimpulan sebagai berikut :

1. Biaya operasional pada PT Gemilang 
Abadi dalam 5 (lima) tahun terakhir yaitu 2013-2017 berfluktuatif. Tahun 2013 biaya operasional sebesar Rp.8.548.784.553, tahun 2014 mengalami penurunan menjadi Rp.7.125.514.453, kemudian tahun 2015 mengalami kenaikan menjadi Rp.8.920.022.175, kemudian tahun 2016 turun menjadi Rp. 8.762.891.353 dan terakhir tahun 2017 mengalami kenaikan menjadi sebesar Rp.8.867.594.334.

2. Profitabilitas dalam 5 (lima) tahun terakhir yaitu 2013-2017 berfluktuatif. Tahun 2013 profitabilitas sebesar 8,51\%, tahun 2014 sedikit mengalami penurunan menjadi 7,12\%, kemudian tahun 2015 mengalami kenaikan menjadi 8,36\%, kemudian tahun 2016 mengalami penurunan menjadi sebesar $6,23 \%$ dan terakhir pada tahun 2017 kembali mengalami penurunan menjadi sebesar $8,01 \%$.

3. Dari hasil pengolahan data diperoleh persamaan regresi linier sederhana $\mathrm{Y}=$ $\mathrm{a}+\mathrm{bx}$ yaitu sebesar $\mathrm{Y}=2,573+0,001 \mathrm{x}$ dimana nilai $b$ bernilai positif $=0,001$ berarti bahwa konstanta sebesar 2,573 diartikan bahwa jika biaya operasional tidak dipertimbangkan atau $(\mathrm{X}=0)$ maka profitabilitas adalah sebesar $0,001 \%$. Dari hasil perhitungan dengan menggunakan metode korelasi diperoleh nilai $r=0,886$ yang berarti terdapat pengaruh yang sangat kuat positif dan signifikan antara biaya operasional terhadap profitabilitas. Berdasarkan hasil analisis koefisien determinasi diperoleh nilai $\mathrm{Kd}=0,785$ yang artinya bahwa pengaruh biaya operasional terhadap profitabilitas adalah sebesar $78,5 \%$ sedangkan sisanya sebesar $21,5 \%$ dipengaruhi oleh faktor-faktor lain. Dari pengujian hipotesis dengan uji $\mathrm{t}$ diperoleh $\mathrm{t}_{\text {hitung }}>\mathrm{t}_{\text {tabel }}(3,312>3,182)$, maka dapat dikatakan positif. Artinya H0 ditolak dan $\mathrm{H} 1$ diterima, berarti terdapat pengaruh positif dan signifikan antara biaya operasional terhadap profitabilitas.

\section{Saran}

Setelah ditarik kesimpulan dari pembahasan yang telah diuraikan diatas, maka disampaikan saran-saran sebagai pertimbangan PT Gemilang Abadi, sebagai berikut :

1. Bagi perusahaan, pengeluaran biaya ope- rasional harus ditargetkan dan direncanakan dengan baik terutama untuk biaya-biaya yang tidak terlalu mendesak. Diharapkan perusahaan akan lebih efisien dan bijak dalam menggunakan dan mengalokasikan biaya operasionalnya. Oleh karena itu, pengendalian biaya perlu dilakukan agar biaya digunakan sesuai dengan yang direncanakan dan pengeluaran biaya tersebut benar-benar dilakukan untuk memperoleh pendapatan agar pendapatan perusahaan dari periode ke periode diharapkan selalu mengalami peningkatan sehingga perusahaan mampu memperoleh tingkat profitabilitas yang maksimal.

2. Untuk dapat menghasilkan profitabilitas yang besar maka PT Gemilang Abadi harus dapat mengoptimalkan potensi pasar pengguna jasa tenaga kerja yang ada melalui peningkatan pelayanan kepada pemakai jasa dan optimalisasi kemampuan tenaga kerja terdididik sehingga dapat menarik masyarakat untuk menggunakan jasa yang dihasilkan oleh perusahaan.

3. Bagipenelitilain yang melakukan penelitian yang sama, disarankan untuk meneliti faktor lain yang dapat mempengaruhi profitabilitas dan lebih berkembang dengan menambah bahasan variabel lain. Selain itu jumlah pengambilan sampel tahun yang lebih banyak serta rentang waktu penelitian yang lebih panjang akan mempretasikan kondisi secara lebih baik lagi.

\section{DAFTAR PUSTAKA}

Agnes Sawir. 2003. Analisa Kinerja Keuangan Dan Perencanaan Keuangan Perusahaan, Jakarta. Penerbit Gramedia Pustaka Utama. Alimsyah dan Padji. 2006. Kamus Istilah Keuangan dan Perperusahaanan. Bandung, Penerbit Rama Widya.

Arikunto dan Suharsimi. 2008. Prosedur Penelitian. Jakarta, Penerbit Rieka Cipta.

Brigham, Eugene dan Joel F. Houston. 2004. Dasar-Dasar Manajemen Keuangan. Edisi Kesepuluh. Jakarta, Salemba Empat.

Carter, William K dan Milton K. Usry. 2004. Akutansi Biaya. Edisi Satu. Cetakan Ketiga Belas. Jakarta, Salemba Empat.

Darsono. 2006. Manajemen Keuangan Pendekatan Praktis. Diaudit Media. Jakarta. 
Eugene F. Brigham dan Joel F. Houstom. 2001. Fundamental of Financial Manajemen. Edisi Kedelapan. Jakarta, Erlangga.

Gibson Charles, "Financial Reporting and Analysis Using Financial Accounting Information", Thomson Learning, South Western, USA, 2001.

Hanafi K.A. 2008. Rancangan Percobaan. Jakarta, Penerbit Raja Grafindo Persada.

Handayanti dan Ruri. 2007. Analisis Pengaruh Biaya Operasional Terhadap Pendapatan Premi Pada PT Asuransi Jiwasraya (Persero) Regional Office Medan, Jurusan Manajemen Fakultas Ekonomi. Universitas Sumatera Utara.

Hansen dan Mowen. 2004. Management Accounting. Edisi ketujuh. Jakarta, Salemba Empat.

Harahap, Sofyan Syafri, 2007. Teori Akuntansi. Edisi Revisi Sembilan. PT. Rajagrafindo Persada. Jakarta.

Harahap, Sofyan Syafri. 2007. Analisis Kritis atas Laporan Keuangan”, Jakarta, Penerbit PT. Raja Grafindo Persada.

Hasan, Iqbal. 2008. Analisis Data Dengan Statistik. Jakarta, Bumi Aksara.

Horne, Van dan Wachowichz. 2005. PrinsipPrinsip Manajemen Keuangan. Edisi Bahasa Indonesia. Jakarta, Salemba Empat.

Husein, Umar. 2008. Metode Penelitian Untuk Skripsi Dan Tesis Bisnis. Jakarta, PT. Raja Grafindo Persada.

Ismaya. 2006. Kamus Akutansi. Cetakan Pertama. Bandung, Pustaka Grafika.

Istijianto. Aplikasi Praktis Riset Pemasaran. Jakarta, Penerbit Gramedia Pustaka Utama.

Jerry J. Weygandt, Kieso. 2006. Akuntansi Intermediet. Jilid Kesatu. Edisi Kesepuluh, Penerbit Erlangga.

John J. Wild K. R. Subramanian. 2005. Financial Statement Analysis. Jakarta, Penerbit, Salemba Empat.

Jusuf, Jopie. 2008. Analisis Kredit. Yogyakarta, Penerbit Andi Offset.

Kasmir. 2004. Bank Dan Lembaga Keuangan Lainnya. Edisi Keenam. Jakarta, Penerbit PT. Raja Grafindo Persada.

Kuncoro. 2009. Metode Riset untuk Bisnis Dan Ekonomi. Edisi Tiga. Jakarta, Penerbit Erlangga.

Linawati. 2006. Pengaruh Biaya Pemasaran Terhadap Tingkat Pendapatan atas Pen- jualan. Studi Kasus Pada PT. Kertas Padalarang, Skripsi, tidak diterbitkan.

Martono dan Agus Harjito. 2010. Manajemen Keuangan. Yogyakarta, Penerbit Ekonisia.

Mulyadi. 2009. Akuntansi Biaya. Edisi Kelima. Cetakan Kesembilan. Yogyakarta, Aditya Media.

Muslich dan Muhammad. 2003. Manajemen Keuangan Moderen. Jakarta, Penerbit Bumi Aksara.

Nafarin, M. 2007. Penganggaran Perusahaan. Salemba Empat. Jakarta.

Pandia Frianto. 2012. Manajemen Dana Dan Kesehatan Bank. Jakarta, Penerbit PT. Rineka Cipta.

Prastowo, Dwi dan Rifka Juliaty. 2005. Analisis Laporan Keuangan Konsep dan Aplikas. Yogyakarta, Upp. Amp YPKN.

Rangkuti. 2009. Analisis SWOT dan Teknik Bedah Kasus. Jakarta, PT. Gramedia Pustaka Utama.

Risandi dan Regi. 2012. Pengaruh Biaya Operasional Terhadap Profitabilitas Perusahaan (Studi Kasus Pada KJPP Rija Husaeni Cabang Tasikmalaya. Jurusan Akuntansi Fakultas Ekonomi. Universitas Siliwangi.

Riyanto dan Bambang. 2007. Dasar-Dasar Pembelanjaan Perusahaan. Yogyakarta, BPFE.

Safri M. Sofyan Harahap. 2004. Budgeting, Penganggaran Perencanaan Lengkap. Cetakan Kedua. Jakarta, PT. Pustaka Quantum.

Sartono, Agus. 2008. Manajemen Keuangan, Teori dan Aplikasi. Yogyakarta, Penerbit BPFE.

Sartono. 2008. Manajemen Keuangan Aplikasi Dan Teori. Edisi Keempat. Yogyakarta, BPFE.

Sarwono, Jonathan. 2006. Metode Penelitian Kuantitatif Dan Kualitatif. Yogyakarta: Graha Ilmu.

Simamora dan Henry. 2006. Akuntansi Basis Pengambilan Keputusan Bisnis. Jakarta, Penerbit Salemba Empat.

Sugiyono. 2014. Metode Penelitian Kuantitatif Kualitatif dan $R$ \& $D$. Bandung, Penerbit CV. Alfabeta.

Sundjaja Ridwan S dan Inge Berlian. 2003. Manajemen Keuangan. Edisi Keempat. Yogyakarta, Literata Lintas Media.

Sundjaja, Ridwan dan Inge Barlian. 2003. 
Manajemen Keuangan 2. Edisi Keempat. Jakarta, Literata Lintas Media

Supangat, Andi. 2003. Statistika Bisni. Bandung, Pustaka.

Supangat, Andi. 2008. Statistika. Jakarta,: Penerbit Kencana.

Supriyono. 2009. Akuntansi Manajemen Proses Manajemen. Yogyakarta, Bagian Penerbitan Sekolah Tinggi Ilmu Ekonomi.

Sutojo, Siswanto. 2008. Menangani Kredit Bermasalah Konsep dan Kasus. Jakarta, Penerbit PT Damar Mulia Pustaka.

Sutrisno, Hadi. 2007. Metodologi Riset Untuk Paper Skripsi. Jilid Tiga. Yogyakarta, Andi Offset.

Sutrisno. 2009. Manajemen Keuangan Teori, Konsep dan Aplikasi. Yogyakarta, Penerbit Ekonisia.

Suwardjono. 2008. Teori Akutansi Perekayasaan Pelaporan Keuangan. Yogyakarta, BPFE.

Syahrul dan Muhammad Afdi Nizar. 2005. Kamus Istilah-istilah Akuntansi. Cetakan Pertama. Jakarta, Citra Harta Prima.

Usman. 2003. Analisis Rasio Keuangan Dalam Memprediksi Laba. Media Riset Bisnis Dan Manajemen. Jakarta.

Weygandt, Kieso. 2006. Intermediate Accounting. John Wiley and Son, Singapore. 